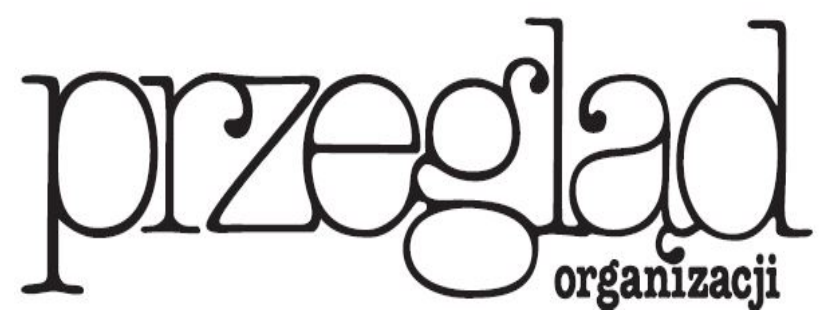

Miesięcznik TNOiK

Założył Karol Adamiecki w 1926 r.

\title{
WYKORZYSTANIE SYSTEMÓW IT \\ W INFORMACYJNYM WSPOMAGANIU WYBORÓW STRATEGICZNYCH W PRZEDSIĘBIORSTWACH DZIAŁAJĄCYCH W RÓŻNYCH SEKTORACH
}

https://doi.org/10.33141/po.2019.04.09

Elżbieta Urbanowska-Sojkin, Adam Weinert
Przegląd Organizacji, Nr 4 (951), 2019, ss. 58-67 www.przegladorganizacji.pl ๑Towarzystwo Naukowe Organizacji i Kierownictwa (TNOiK)

\section{Wprowadzenie}

$\mathbf{P}$

roblematyka informacyjnego wspomagania wyborów strategicznych przedsiębiorstw jest coraz bardziej popularna $\mathrm{w}$ literaturze $\mathrm{z}$ zakresu nauk o zarządzaniu, a w szczególności przez umiejscowienie bezpośrednio w obszarze zarządzania strategicznego (Wheelen, Hunger, 2012; Peppard, Ward, 2016; Urbanowska-Sojkin, 2017) oraz pośrednio $\mathrm{w}$ dziedzinie informatyki ekonomicznej (Pearlson i in., 2016; Banaszak i in., 2016; Olszak, 2017).

W dynamicznych, niepewnych i złożonych warunkach funkcjonowania przedsiębiorstw, wywołanych zwłaszcza ideą cyfrowej transformacji, za nieuniknione uznaje się wykorzystywanie przez przedsiębiorstwa systemów infor- 
matycznych zarządzania z coraz bardziej funkcjonalnymi rozwiązaniami opartymi na technologiach stanowiących podstawę realizacji wytycznych koncepcji Przemysłu 4.0. Nowoczesne systemy analityczne pozwalają na zautomatyzowanie zbierania, gromadzenia i przetwarzania dużych, zmiennych, różnorodnych zbiorów danych oraz warunkują procesy podejmowania decyzji (Herbert, 2017, s. 7).

Przedmiotem zainteresowania w opracowaniu są uwarunkowania procesu informacyjnego wspomagania wyborów strategicznych w przedsiębiorstwach przez systemy IT. Do czynników, które determinują poziom zaawansowania informacyjnego wspomagania wyborów strategicznych przedsiębiorstwa, należy sektor działalności gospodarczej. Skutkiem tego jest między innymi oferta producentów rozwiązań systemów IT dedykowana poszczególnym branżom (np. SAP, SAS, Microsoft, IFS, BPSC, Oracle, Comarch, Streamsoft, Unit4, Simple, Sage).

$\mathrm{W}$ artykule na podstawie analizy literatury oraz identyfikowanych trendów w praktyce (statystyki i analizy GUS) sformułowano hipotezę badawczą: przedsiębiorstwa funkcjonujące w różnych sektorach działalności gospodarczej charakteryzują się odmiennym poziomem wykorzystania systemów IT w wyborach strategicznych.

Przesłanki zainteresowania sektorowym różnicowaniem zaawansowania informacyjnego wspomagania zarządzania strategicznego wynikają z elementów ekonomii sektorowej oraz z nurtu dynamiki konkurencyjnej (Matyjas, 2013). Są nimi przede wszystkim atrybuty sektorów wyrażane przez skalę i przedmiot działań gospodarczych, produkty i ich zróżnicowanie; przez stopień koncentracji w sektorze, metody i techniki działania, w tym konkurowania, kooperacji; przez fazę cyklu życia sektora; powiązania międzyorganizacyjne w sektorach, zaawansowanie technologiczne i działania innowacyjne oraz inwestowanie w pozycje rynkowe. Nie bez znaczenia jest polityka rządu względem poszczególnych sektorów. W cechach obiektywnie opisujących sektory działania upatrywano spełniania roli moderowania informacyjnego wspomagania zarządzania strategicznego. Aktualnie dostępne informacje o ekonomicznych i organizacyjnych cechach sektorów gospodarczych znakomicie ograniczyły spełnienie pierwotnych zamiarów badawczych. Wybrane cechy identyfikujące sektory pozwoliły na stworzenie przekrojów analiz ze względu na przedmiot działania oraz poziom wykorzystania technologii - systemów IT, co odpowiada profilowi sektora wg identyfikacji stosowanej przez Główny Urząd Statystyczny w Polsce. Celem opracowania jest określenie poziomu wykorzystania przez przedsiębiorstwa działające w różnych sektorach systemów IT wspomagających wybory strategiczne.

W badaniach i konsekwentnie w opracowaniu przyjęto założenie, że sektor działalności gospodarczej jest rozumiany zgodnie z układem i charakterystyką stosowanymi w Polskiej Klasyfikacji Działalności (PKD), która została opracowana na podstawie Statystycznej Klasyfikacji Działalności Gospodarczej Unii Europejskiej NACE Rev.2. Tak rozumiane kryterium - „sektor działania” - stało się podstawą analizy informacyjnego wspomagania wyborów strategicznych w przedsiębiorstwach. Polska Klasyfikacja Działalności jest umownie przyjętym podziałem zbioru rodzajów działalności społeczno-gospodarczej (sekcje A-U) (GUS, 2017, s. 19-20). Warunkiem zaliczenia jednostki (podmiotu gospodarczego) do danej grupy jest przeważający przedmiot podstawowej działalności gospodarczej (sekcje A-L).

W opracowaniu wsparciem dla wiedzy teoretycznej są dane empiryczne zebrane $\mathrm{w}$ ramach badań prowadzonych przez Katedrę Zarządzania Strategicznego UEP w 2017 roku wśród członków najwyższego szczebla kierownictwa średnich i dużych przedsiębiorstw kwalifikujących się do jednego z 12 sektorów działalności gospodarczej. Część wyników badań została wykorzystana w pracy doktorskiej (Weinert, 2018). Narzędziem pomiarowym był kwestionariusz elektroniczny ankiety. Wielkość próby badawczej wyniosła 306 obserwacji. Uzyskane wyniki badań dotyczą wybranych cech informacyjnego wspomagania wyborów strategicznych przez systemy IT w przedsiębiorstwach i szerzej komputerowego wsparcia zarządzania strategicznego.

\section{Informacyjne wspomaganie wyborów strategicznych przez systemy IT}

\section{Podłoże teoretyczne informacyjnego wspomagania wyborów strategicznych}

$\mathbf{P}$ odstawy informacyjnego wspomagania wyborów strategicznych stanowią ustalenia naukowe ujęte $\mathrm{z}$ dwóch perspektyw. Pierwsza związana jest stricte $\mathrm{z}$ teoriami podejmowania decyzji (strategicznych), druga z systemami informacyjnymi i informatycznymi zarządzania. Interesujące zestawienie teorii $\mathrm{w}$ tym zakresie prezentują K.R. Larsen, G. Allen, A. Vance i D. Eargle (2014). Wśród wybranych 106 teorii (które nadal są uzupełniane w bazie internetowej) wskazano przede wszystkim teorię zasobową, teorię dynamicznych zdolności, teorię interesariuszy, teorię agencji, teorię instytucjonalną oraz teorię procesu informacyjnego. Warto zauważyć, że według T.P. Kenworthy'ego i A. Verbeke (2015) wśród nich są teorie naukowe należące do dorobku w zakresie zarządzania strategicznego. Interesujące rozważania podejmuje A.R. Burgelman wraz z zespołem (2018). Na podstawie analizy literatury z lat 1992-2016 badacze wyznaczyli główne kierunki zainteresowania teoriami zarządzania strategicznego, wśród nich te warunkowane rozwojem informacyjnego i informatycznego wspomagania. Przydatność wybranych teorii przedstawiono w tabeli 1.

\section{Rola systemów IT w informacyjnym wspomaganiu wyborów strategicznych}

$\mathrm{W}$ artykule wybory strategiczne rozumiane są w szerszym znaczeniu, czyli w ujęciu procesowym, na które składają się cztery fazy, zgodnie ze wskazaną kolejnością: rozpoznanie problemów strategicznych, rozpoznanie wewnętrznych i zewnętrznych warunków działania, sformułowanie opcji strategicznych, wybór strategiczny - podjęcie ostatecznej decyzji (Urbanowska-Sojkin, 2013, s. 79).

W ujęciu funkcjonalnym system informacyjny pomaga $\mathrm{w}$ rzetelnym analizowaniu otoczenia, eksplorowaniu i identyfikowaniu warunków działania, eksperymentowaniu i kontrolowaniu wielu działań przedsiębiorstwa 
(Wheelen, Hunger, 2012, s. 347). Rola systemów informacyjnych rozważana $\mathrm{w}$ kontekście zarządzania strategicznego polega na dostarczaniu informacji do podejmowania decyzji o charakterze strategicznym. To oznacza, że systemy informacyjne służą określeniu możliwych sposobów zachowania przedsiębiorstwa $\mathrm{w}$ przyszłości poprzez dostarczanie informacji użytecznych dla określenia, poddanych dalszej analizie i ocenie, możliwych do zastosowania wariantów działania. Służebność systemów informacyjnych względem zarządzania strategicznego dotyczy także monitorowania i oceny skutków decyzji strategicznych. Informacje te muszą być gromadzone (automatyczne pobieranie $\mathrm{z}$ różnych urządzeń), przechowywane i opracowywane syntetycznie $\mathrm{w}$ atrakcyjny sposób (forma prezentacji i łatwości dostępu danych, np. poprzez kokpity menedżerskie), aby odpowiadały na ważne pytania i problemy strategiczne (Urbanowska-Sojkin, 2010 , s. 207-208). Zakres informacyjnego wspomagania $\mathrm{w}$ poszczególnych fazach procesu wyborów strategicznych zaprezentowano $w$ tabeli 2.

Systemy IT tworzą podstawy informacyjnego wspomagania decyzji poprzez infrastrukturę informatyczną, pozwalającą pozyskiwać informacje o odpowiedniej jakości i we właściwym czasie, gromadzonych z różnych obszarów funkcjonalnych przedsiębiorstwa oraz z innych systemów, a także pozyskanych $\mathrm{z}$ wielu, najczęściej rozproszonych, źródeł zewnętrznych (Banaszak i in., 2016, s. 129). Główną rolę wśród nich pełnią rozwijane, szczególnie intensywnie przez ostatnie 20 lat, systemy klasy ERP. Stanowią one obecnie pod względem funkcjonalnym najbardziej "dojrzałe" systemy IT, charakteryzujące się szerokim zakresem użytkowania, co pozwala zwiększać racjonalność podejmowanych decyzji w przedsiębiorstwie (Olszak, 2017). Niezbędnym uzupełnieniem systemów ERP są przede wszystkim systemy klasy BI, CRM, DMS, BPM, traktowane często również jako aplikacje komplementarne ${ }^{1}$. W różnym zakresie pozwalają one na poprawę jakości i przebiegu wyborów strategicznych, potencjalizując ich trafność i skuteczność (Pearlson i in., 2016, s. 64).

Informatyczne oprogramowanie użytkowe przynosi korzyści bezpośrednio postrzegane i oceniane przez „uprawnionego" użytkownika. Jego konfiguracja w systemach zarządzania umożliwia nie tylko zarządzanie bieżącą działalnością, ale także dokonywanie pomiaru rezultatów realizowanych celów strategicznych i strategii. Służy także do kreowania i wykorzystywania przyszłych możliwości rozwoju przedsiębiorstwa. Jest związane zatem $\mathrm{z}$ tworzeniem konkurencyjności i przewagi konkurencyjnej

Tabela 1. Wybrane teorie dotyczące informacyjnego wspomagania wyborów strategicznych

\begin{tabular}{|c|c|c|}
\hline Teoria & Główni autorzy & $\begin{array}{l}\text { Przydatność teorii dla opisu i wyjaśniania informacyjnego } \\
\text { wspomagania wyborów strategicznych }\end{array}$ \\
\hline Teoria zasobowa & $\begin{array}{l}\text { E. Penrose, J. Barney, } \\
\text { B. Wernerfelt }\end{array}$ & $\begin{array}{l}\text { Wsparcie informacyjne dla wyborów strategicznych upatruje się w działaniach polegających } \\
\text { na integrowaniu zasobów, ich budowie, rekonfiguracji, po to, by generować nowe rozwiązania } \\
\text { problemów strategicznych. }\end{array}$ \\
\hline $\begin{array}{l}\text { Teoria dynamicznych } \\
\text { zdolności }\end{array}$ & D. Teece, K. Eisenhardt & $\begin{array}{l}\text { Utrwalenie przekonania, że zdolności dynamiczne pozwalają przedsiębiorstwu adaptować } \\
\text { się szybciej i dokładniej do wszelkich zmian. Należą do nich zdolności do informacyjnego } \\
\text { wspomagania wyborów strategicznych. }\end{array}$ \\
\hline Teoria interesariuszy & R.E. Freeman & $\begin{array}{l}\text { Potwierdzenie, że interesariusze mogą wywierać wpływ na przebieg i jakość procesu wyborów } \\
\text { strategicznych (interakcje - relacje; komunikacja; grupy interesu). }\end{array}$ \\
\hline Teoria agencji & $\begin{array}{l}\text { A. Alchian, H. Demsetz, } \\
\text { K. Eisenhardt, } \\
\text { M. Jensen, W. Meckling }\end{array}$ & $\begin{array}{l}\text { Sformułowanie konwencji - zarządzanie relacjami pryncypał-agent w odniesieniu do osób } \\
\text { zaangażowanych w informacyje wspomaganie procesu wyborów strategicznych jest konieczne. }\end{array}$ \\
\hline $\begin{array}{l}\text { Teoria } \\
\text { instytucjonalna }\end{array}$ & $\begin{array}{l}\text { P. Selznick, P.J. DiMaggio, } \\
\text { W.W. Powell, W.R. Scott, } \\
\text { G.L. Zucker }\end{array}$ & $\begin{array}{l}\text { Nasilenie informacyjnego wspomagania wyborów strategicznych może oznaczać odejście od } \\
\text { wymogów otoczenia instytucjonalnego i instytucjonalnego kryterium racjonalności, a w związku } \\
\text { z tym należy uwzględniać negatywne reakcje ukierunkowane na poszczególnych interesariuszy. }\end{array}$ \\
\hline $\begin{array}{l}\text { Teoria procesu } \\
\text { informacyjnego }\end{array}$ & G.A. Miller & $\begin{array}{l}\text { Informacja jest uznawana za najważniejszy składnik każdego systemu (w tym systemów } \\
\text { wspomagających wybory strategiczne), ponieważ wprowadza ład i uporządkowanie. }\end{array}$ \\
\hline
\end{tabular}

Źródło: opracowanie na podstawie: Larsen i in., 2014; Kenworthy, Verbeke, 2015

Tabela 2. Informacyjne wspomaganie procesu wyborów strategicznych

\begin{tabular}{|l|l|l|}
\hline \multicolumn{1}{|c|}{ Faza procesu wyborów strategicznych } & \multicolumn{1}{|c|}{ Opis } & \multicolumn{1}{|c|}{ Forma informacyjnego wspomagania } \\
\hline Rozpoznanie problemów strategicznych & $\begin{array}{l}\text { Percepcja symptomów problemu i rejestracja } \\
\text { problemu }\end{array}$ & Dostarczanie informacji \\
\hline $\begin{array}{l}\text { Rozpoznanie wewnętrznych i zewnętrznych } \\
\text { warunków działania }\end{array}$ & Wyjaśnienie problemów strategicznych & Dostarczanie informacji \\
\hline Sformułowanie opcji strategicznych & $\begin{array}{l}\text { Ustalenie potencjalnych sposobów } \\
\text { postępowania - identyfikacja wariantów }\end{array}$ & $\begin{array}{l}\text { Określenie możliwych sposobów zachowania } \\
\text { przedsiębiorstwa }\end{array}$ \\
\hline $\begin{array}{l}\text { Wybór strategiczny - podjęcie ostatecznej } \\
\text { decyzji }\end{array}$ & $\begin{array}{l}\text { Określenie dopuszczalnych wariantów oraz ich } \\
\text { ocena }\end{array}$ & $\begin{array}{l}\text { Dostarczanie informacji dla sfomułowania } \\
\text { wariantów i oceny decyzji }\end{array}$ \\
\hline
\end{tabular}

Źródło: opracowanie własne 
(Peppard, Ward, 2016, s. 17; Urbanowska-Sojkin, 2017, s. 403). Wśród wdrażanych pakietów aplikacji IT znajdują się narzędzia implementowane do budowania wiedzy o przyszłym otoczeniu oraz o możliwościach rozwoju w nim przedsiębiorstwa (np. umożliwiające budowę scenariuszy rozwoju otoczenia, sporządzenie i wykorzystanie strategicznej karty wyników oraz konstruowanie i analizę map strategicznych) (Jarzabkowski, Kaplan, 2015, s. 539).

Krytyczna analiza dorobku naukowego w zakresie informacyjnego wspomagania wyborów strategicznych przez systemy IT pozwoliła stwierdzić, że przedmiotowe badania $\mathrm{w}$ przedsiębiorstwach $\mathrm{w}$ Polsce były podejmowane relatywnie rzadko. Powodem tego jest niezwykle złożony zakres przedmiotowy problematyki wyborów strategicznych ${ }^{2}$.

W warstwie informacyjnej warunkującej wybory strategiczne należy uwzględniać wszelkie uwarunkowania popytowe i podażowe w przyszłości oraz czynniki oddziałujące na ich poziom i strukturę rodzajową. Konieczne są między innymi informacje o segmentach docelowych, ich ewolucji i jej siłach napędowych, oczekiwanej przez klientów wartości i zmianach w czasie, a także możliwościach sprostania wyzwaniom $\mathrm{z}$ otoczenia przez przedsiębiorstwa (Urbanowska-Sojkin, 2014, s. 155). Menedżerowie wiążą sprostanie potrzebom informacyjnego wspomagania wyborów strategicznych z rozwojem koncepcji Przemysłu 4.0 - związanej z cyfryzacją gospodarki, a w szczególności przemysłu i strategii produkcyjnych $\mathrm{w}$ przedsiębiorstwach. Wraz z rozwojem tej koncepcji badania naukowców są coraz częściej zorientowane na rozwiązania techniczno-technologiczne, takie jak: roboty współpracujące i roboty autonomiczne, systemy symulacji (digital twin), Internet Rzeczy (a także usług, ludzi, danych), rozszerzona i wirtualna rzeczywistość, Blockchain oraz model przetwarzania w chmurze obliczeniowej, które zwiększają możliwości standardowych systemów IT. Jednocześnie wymienione przykłady to przedmiot zainteresowania aktualnie ważnych nurtów zmian technologicznych w przedsiębiorstwach (Ghobakhloo, 2018, s. 914). Nie sposób pominąć również systemów Big Data (stanowiących jeden $\mathrm{z}$ elementów koncepcji Przemysłu 4.0) ze względu na ich szczególną użyteczność w zakresie podejmowania decyzji strategicznych, które w połączeniu z systemami CRM, BI i ERP zwiększają możliwości analityczno-raportowe opisujące i wyjaśniające różne obszary funkcjonalne przedsiębiorstwa (Weinert, 2017a).

Wobec wspomnianego szerokiego zakresu przedmiotowego problematyki wyborów strategicznych i licznych sposobów informacyjnego i informatycznego wspomagania wszechstronna ocena przedsiębiorstw jest możliwa tylko na określonym poziomie ogólności i wymaga przyjęcia odpowiednich założeń badawczych. W niniejszym artykule skoncentrowano się na wdrożeniach standardowych klas systemów IT (ERP, BI, CRM, DMS, BPM), użytecznych w kontekście procesu wyborów strategicznych, a umożliwiających rozpoznawanie przyszłych warunków działania oraz sposobów radzenia z problemami rozwoju i zachowania rynkowego. Są to typy systemów wymieniane najczęściej przez twórców systemów IT, producentów i dostawców oprogramowania jako wspomagające wybory strategiczne. O nich traktują także treści opracowań naukowych stanowiące pokłady teoretyczne informacyjnego wspomagania zarządzania strategicznego prezentowane w literaturze przedmiotu.

\section{Typologia systemów IT wspomagających wybory strategiczne}

W badaniu przedstawionym w dalszej części artykułu w punkcie wyjścia wskazano generacje systemów IT $\mathrm{z}$ uwzględnieniem ich podziału na - systemy podstawowe, systemy transakcyjne, systemy informowania kierownictwa, systemy doradcze oraz systemy kompleksowe. Ze względu na to, że nie sposób uwzględnić w badaniach empirycznych wszystkich możliwych systemów zaliczanych do danej generacji, wykorzystano szczegółową typologię systemów IT wspomagających wybory strategiczne stworzoną na podstawie podziałów dokonanych przez teoretyków, badaczy i doświadczonych konsultantów IT. Są one zawarte w pracach między innymi J. Kisielnickiego (2009), K.C. Laudona i J.P. Laudon (2014), J. Jurka (2016) oraz B. Wachnika (2016).

W tabeli 3 zaprezentowano możliwości informacyjnego wspomagania procesu wyborów strategicznych przez wybrane klasy systemów IT oraz ich różne konfiguracje, a także przykłady oprogramowania $z$ rodziny systemów zaprojektowanych przez firmę Microsoft (Microsoft Dynamics NAV, 2018) oraz polskiego dostawcę rozwiązań IT - Comarch (www.comarch.pl).

Analiza klas systemów IT pozwala stwierdzić, że służą one $\mathrm{w}$ różnym zakresie $\mathrm{i} \mathrm{w}$ różnej formie wspomaganiu każdej z faz procesu wyborów strategicznych. Systemy te podzielono ze względu na charakter informacyjnego wspomagania: wspomaganie pośrednie - wyłącznie pomocnicze (np. systemy biurowe, systemy szyfrujące, systemy wspomagania edukacji), wspomaganie bezpośrednie: ERP, DMS, BPM, CRM interakcyjny i operacyjny, BI, CRM analityczny, ERP z modułami odpowiadającymi systemom BI, CRM, DMS, BPM.

Wymienione klasy systemów IT z coraz większą determinacją uzupełniają portfel narzędzi użytecznych w sprawowaniu ról przez strategów we współczesnym przedsiębiorstwie, zwłaszcza $\mathrm{w}$ dobie cyfrowej transformacji (Weinert, 2017b).

\section{Metodyka badawcza}

Podmiotem badań były średnie i duże przedsiębiorstwa (według liczby zatrudnionych pracowników), reprezentowane przez głównych strategów (przedstawiciele najwyższego szczebla kierownictwa, w tym - właściciele, prezesi, członkowie zarządu, dyrektorzy generalni, dyrektorzy wykonawczy, dyrektorzy strategiczni i zarządzający). Sektor prowadzonej działalności gospodarczej, jak wcześniej wspomniano, ustalono zgodnie z Polską Klasyfikacją Działalności (PKD) w ramach poszczególnych sekcji (wybrano sekcje od A do L).

Do weryfikacji wskazanej we wprowadzeniu do artykułu hipotezy badawczej posłużyły odpowiedzi zebrane na podstawie pytań kwestionariusza ankiety elektronicznej, 
Tabela 3. Informacyjne wspomaganie procesu wyborów strategicznych przez systemy IT z przykładami oprogramowania użytkowego

\begin{tabular}{|c|c|c|c|c|}
\hline Kryterium & \multicolumn{4}{|c|}{ Proces wyborów strategicznych } \\
\hline Generacja systemów IT & Systemy podstawowe & $\begin{array}{l}\text { Systemy transakcyjne / } \\
\text { Systemy informowania } \\
\text { kierownictwa }\end{array}$ & Systemy doradcze & $\begin{array}{c}\text { Systemy kompleksowe } \\
\text { (zintegrowane) }\end{array}$ \\
\hline $\begin{array}{l}\text { Standardowa klasa } \\
\text { systemu IT }\end{array}$ & (np. biurowe) & ERP, DMS, BPM, CRM & BI, CRM & $\begin{array}{c}\text { ERP z modułami } \\
\text { odpowiadającymi } \\
\text { systemom BI, CRM, DMS, } \\
\text { BPM }\end{array}$ \\
\hline $\begin{array}{l}\text { Wpływ na proces } \\
\text { wyborów }\end{array}$ & Brak wpływu & $\begin{array}{l}\text { Umożliwienie przebiegu } \\
\text { procesu }\end{array}$ & $\begin{array}{l}\text { Usprawnienie i poprawa } \\
\text { jakości procesu }\end{array}$ & $\begin{array}{c}\text { Umożliwienie przebiegu, } \\
\text { usprawnienie i poprawa } \\
\text { jakości procesu }\end{array}$ \\
\hline $\begin{array}{c}\text { Charakter wspomagania } \\
\text { wyborów }\end{array}$ & $\begin{array}{l}\text { Pośredni (wyłącznie } \\
\text { pomocniczy) }\end{array}$ & \multicolumn{3}{|c|}{ Bezpośredni (w różnym zakresie) } \\
\hline $\begin{array}{c}\text { Forma wspomagania } \\
\text { wyborów }\end{array}$ & $\begin{array}{c}\text { Przedstawienie } \\
\text { pozyskanych informacji }\end{array}$ & $\begin{array}{c}\text { Dostarczenie podstawowej } \\
\text { informacji dla } \\
\text { tworzenia przyszłości } \\
\text { przedsiębiorstwa, } \\
\text { w większości dotyczące } \\
\text { analiz historycznych } \\
\text { i bieżącej działalności }\end{array}$ & $\begin{array}{l}\text { Dostarczenie kluczowych } \\
\text { informacji i proponowanie } \\
\text { rozwiązań dotyczących } \\
\text { bieżącej i przyszłej } \\
\text { działalności }\end{array}$ & $\begin{array}{c}\text { Kompleksowe dostarczanie } \\
\text { informacji i proponowanie } \\
\text { rozwiązań dotyczących } \\
\text { bieżącej i przyszłej } \\
\text { działalności }\end{array}$ \\
\hline \multicolumn{5}{|c|}{ Przykłady oprogramowania użytkowego } \\
\hline Microsoft & MS Office, Office 365 & Microsoft Dynamics CRM & $\begin{array}{l}\text { Power BI, Cortana } \\
\text { Intelligence Suite }\end{array}$ & $\begin{array}{c}\text { Microsoft Dynamics NAV } \\
2018\end{array}$ \\
\hline Comarch & - & $\begin{array}{c}\text { Comarch DMS, Comarch } \\
\text { Mobile }\end{array}$ & Comarch BI Point & $\begin{array}{l}\text { Comarch ERP Altum, } \\
\text { Comarch ERP XL }\end{array}$ \\
\hline
\end{tabular}

Źródło: opracowanie własne

który został wcześniej udostepniony na dedykowanej stronie internetowej (https://strategicznie.pl). Badanie zostało oparte na gromadzeniu danych w sposób zamknięty. Jako operat losowania wykorzystano bazę danych EMIS Professional, za pomocą której uzyskano dostęp do wykazu jednostek (populacji badanej), zawierającego aktualne dane kontaktowe. W badaniu zastosowano formułę doboru kwotowo-losowego (mieszanego). Losowanie podmiotów gospodarczych do badania w ramach poszczególnych podgrup miało charakter losowania prostego (bez zwracania).

Dane empiryczne uzyskane w wyniku przeprowadzonej procedury badawczej poddano wielowymiarowej analizie statystycznej. Zastosowano metodę analizy danych sumarycznych mierników statystycznych (skala nominalna - trzystopniowa) oraz metodę porównania różnic pomiędzy badanymi grupami przy wykorzystaniu testu U (Manna-Whitneya) dla prób niezależnych. Test $U$ jest powszechnie stosowaną metodą oceny, gdy analizowane dane nie spełniają założeń przewidzianych dla testów parametrycznych (Bedyńska, Cypryańska, 2013, s. 185). W badaniach wykorzystano również tzw. tabele kontyngencji. Ich szczegółowe wyniki zostały przedstawione w skróconej wersji ze względu na wymaganą objętość artykułu. Do analizy danych wykorzystano program IBM SPSS Statistics (ver. 21).

Materiał empiryczny uzyskano łącznie od 306 przedsiębiorstw prowadzących działalność na terenie Polski w 2017 roku (badanie ilościowe, wsparte zostało wcześniejszym badaniem jakościowym - wśród ekspertów, a także badaniem pilotażowym). Badana populacja ze względu na liczebność zbioru należy do populacji skończonej. W cza- sie rozpoczęcia badań (pierwsza połowa 2017 roku) wśród dużych i średnich przedsiębiorstw prowadzących działalność na terenie Polski dominowały podmioty zatrudniające od 50 do 249 osób. W przebadanej próbie również te przedsiębiorstwa stanowiły największy zbiór $(86,93 \%$ - 266 podmiotów). Pozostałe podmioty należały do kategorii dużych przedsiębiorstw (powyżej 249 osób) (13,07\% - 40 podmiotów, w tym przedsiębiorstw zatrudniających powyżej 1000 pracowników, 4,57\% - 14 podmiotów).

\section{Wybrane wyniki badań wykorzystania systemów IT $w$ wyborach strategicznych przedsiębiorstw}

\section{Udziat przedsiębiorstw ze względu na sektor działalności gospodarczej}

0 trzymana struktura badanych przedsiębiorstw ze względu na kryterium sektora działalności gospodarczej przedstawia się następująco:

A) Rolnictwo, leśnictwo, łowiectwo i rybactwo $(6,86 \%$ -21 podmiotów).

B) Górnictwo i wydobywanie (0,00\% - brak podmiotów).

C) Przetwórstwo przemysłowe (14,05\% - 43 podmioty).

D) Wytwarzanie i zaopatrywanie w energię elektryczną, gaz, parę wodną i gorącą wodę (5,88\% - 18 podmiotów).

E) Dostawa wody, gospodarowanie ściekami i odpadami, rekultywacja ( $4,58 \%$ - 14 podmiotów).

F) Budownictwo (11,76\% - 36 podmiotów).

G) Handel, naprawa pojazdów samochodowych (15,36\% - 47 podmiotów). 
H) Transport i gospodarka magazynowa $(11,76 \%$ - 36 podmiotów).

I) Zakwaterowanie i gastronomia (5,88\% - 18 podmiotów).

J) Informacja i komunikacja $(9,80 \%-30$ podmiotów).

K) Działalność finansowa i ubezpieczeniowa $(8,82 \%$ - 27 podmiotów).

L) Obsługa rynku nieruchomości (5,23\% - 16 podmiotów). Porównanie struktury populacji generalnej (w chwili rozpoczęcia badania przedsiębiorstw tych w Polsce było ok. 18430 (GUS, 2017, s. 30-49)) i przebadanej próby przedsiębiorstw wykazało od 2 do 6 punktów procentowych różnicy w poszczególnych sekcjach. W przypadku niektórych sekcji wystąpiła tzw. nadreprezentacja danych. Dlatego też ostatecznie dobór próby przyjął charakter nieproporcjonalny. Nie bez znaczenia dla oceny informacyjnego wspomagania wyborów strategicznych są perspektywy rozwoju przedsiębiorstw i inwestycji w systemy informatyczne. W ostatnich latach obserwuje się wzrost inwestycji przedsiębiorstw w Polsce, w tym w zakresie infrastruktury informacyjnej i informatycznej powodowane stabilną i dobrą sytuacją ekonomiczną przedsiębiorstw oraz kształtowaniem wielkości i struktury popytu (NBP, 2018, s. 24). Do sektorów, w których przedsiębiorstwa poniosły największe nakłady na zakup sprzętu ICT (w \% ogółu przedsiębiorstw danej grupy) w 2017 roku, należą podmioty zajmujące się: działalnością finansową i ubezpieczeniową (77,5\%), wytwarzaniem i zaopatrywaniem w energię elektryczną, gaz, parę wodną i gorącą wodę $(65,6 \%)$, informacją i komunikacją $(62,1 \%)$ oraz obsługą rynku nieruchomości (55,2\%) (GUS, 2018, s. 110-111).

Poziom informatyzacji w średnich i dużych przedsiębiorstwach w Polsce wyrażony posiadanymi systemami informatycznymi (klasy ERP i CRM) z roku na rok rośnie (od 2014 roku). Z drugiej strony, niepokojąca jest wartość wskaźnika „intensywności cyfrowej” (digital intensity index) dla przedsiębiorstw w Polsce, który w 2017 roku był o 7,4 punktów procentowych niższy niż średni dla całej Unii Europejskiej (21,5\%). Do warunków określających poziom intensywności cyfrowej, oprócz takich elementów jak posiadanie strony internetowej, korzystanie z mediów społecznościowych, wlicza się również posiadanie oprogramowania klasy ERP oraz CRM (GUS, 2018, s. 111-113).

\section{Poziom wykorzystania systemów IT w wyborach strategicznych przez przedsiębiorstwa działające $w$ różnych sektorach}

Otrzymane w efekcie badania wyniki zaprezentowano w tabelach 4 i 5 . Ocenie wykorzystania przez przedsiębiorstwa systemów IT w wyborach strategicznych poddano pięć klas systemów - systemy klasy DMS, BPM, CRM, BI, ERP.

Wyniki badania wskazują, że poziom wykorzystania systemów IT w przedsiębiorstwach jest zróżnicowany (tab. 4). Jedną z przyczyn są wcześniej, w poprzednich latach wdrożone przez przedsiębiorstwa systemy, nadal eksploatowane, które mają ograniczone możliwości rozpoznawania i prognozowania przyszłych warunków działania oraz kształtowania przyszłości przedsiębiorstw.

Odpowiedzi respondentów na pytanie dotyczące dokonanych wcześniej wyborów systemu IT i aktualnie eksploatowanych wskazują na to, że zdecydowanie najwięcej przedsiębiorstw korzysta z systemów klasy BPM $(66,67 \%$ - 204 podmioty). Systemy te $\mathrm{w}$ mniejszym zakresie służą dostarczeniu informacji dla tworzenia przyszłości przedsiębiorstwa, a w większym umożliwiają dokonanie analiz historycznych i bieżącej działalności, a w szczególności informowanie o przebiegu kluczowych procesów biznesowych w przedsiębiorstwie. W opinii respondentów, w kontekście dynamicznych zmian w otoczeniu wzbogacanie baz danych i funkcji systemów jest w odniesieniu do tych systemów imperatywem. Pozwoli to na wykorzystanie w praktyce efektów przetwarzania danych. Praktycy, w rolach respondentów w badaniach, stwierdzają, że rozbudowa baz, funkcji i narzędzi informatycznych sprzyjają wzrostowi efektywności działań i skuteczności realizacji celów strategicznych.

Zdecydowanie mniejsza część uczestniczących w badaniu przedsiębiorstw wykorzystuje "zaawansowane systemy IT”. Wśród nich, zaliczane do kompleksowych systemów IT, systemy klasy ERP (26,14\% - 80 podmiotów korzysta z funkcjonalności tych systemów w procesach wyborów strategicznych). Inny poziom wskazań charakteryzuje korzystanie z systemów klasy BI. Są one określane jako "najbardziej zaawansowana kategoria systemów doradczych”, zorientowana na gromadzenie (zbieranie), eksplorację, przetwarzanie (analizę danych), wizualizację oraz udostępnianie wiedzy korporacyjnej. Ponad $1 / 3$ respondentów $(34,64 \%$ - 106 podmiotów) wykorzystuje systemy klasy BI w wyborach strategicznych, co prowadzi

Tabela 4. Poziom wykorzystania systemów IT przez przedsiębiorstw do informacyjnego wspomagania wyborów strategicznych (N=306)

\begin{tabular}{|c|c|c|c|c|c|}
\hline \multirow{2}{*}{ Generacja systemów IT } & \multirow{2}{*}{ Klasa systemów IT } & \multicolumn{3}{|c|}{ Wyniki w \% } & \multirow{2}{*}{ Ocena wyników* } \\
\hline & & $\mathrm{T}$ & NW & $\mathbf{N}$ & \\
\hline \multirow{2}{*}{$\begin{array}{l}\text { Systemy informowania } \\
\text { kierownictwa }\end{array}$} & DMS & 33,33 & 18,95 & 47,71 & Niska \\
\hline & BPM & 66,67 & 5,88 & 27,45 & Wysoka \\
\hline \multirow{2}{*}{ Systemy doradcze } & CRM & 44,44 & 16,34 & 39,22 & Umiarkowana \\
\hline & $\mathrm{BI}$ & 34,64 & 15,03 & 50,33 & Niska \\
\hline Systemy kompleksowe & ERP & 26,14 & 13,73 & 60,13 & Niska \\
\hline
\end{tabular}

Legenda: T - Tak (mamy wdrożony i wykorzystujemy ten system); NW - Nie wiem/nie mam zdania; N - Nie; * w porównaniu do wszystkich otrzymanych rezultatów w badaniu

Źródło: opracowanie własne 
Tabela 5. Poziom wykorzystania systemów IT do informacyjnego wspomagania wyborów strategicznych w przedsiębiorstwach dziatających w różnych sektorach $(\mathrm{N}=306)$

\begin{tabular}{|c|c|c|c|c|c|c|c|c|c|c|c|c|}
\hline \multirow{3}{*}{ Sekcja PKD* } & \multicolumn{10}{|c|}{ Klasa systemu IT (wyniki w \%) } & \multirow{2}{*}{\multicolumn{2}{|c|}{ N_W }} \\
\hline & \multicolumn{2}{|c|}{ DMS } & \multicolumn{2}{|c|}{ BPM } & \multicolumn{2}{|c|}{ CRM } & \multicolumn{2}{|c|}{ BI } & \multicolumn{2}{|c|}{ ERP } & & \\
\hline & $* *$ & $* * *$ & $* *$ & $* * *$ & $* *$ & $* * *$ & $* *$ & $* * *$ & ** & $* * *$ & $* *$ & $* * *$ \\
\hline A & 23,8 & 4,9 & 81,0 & 8,3 & 38,1 & 5,9 & 33,3 & 6,6 & 33,3 & 8,8 & BPM & ERP \\
\hline $\mathrm{C}$ & 34,9 & 14,7 & 76,7 & 16,2 & 55,8 & 17,6 & 41,9 & 17,0 & 23,3 & 12,5 & BPM & CRM \\
\hline $\mathrm{D}$ & 38,9 & 6,9 & 88,9 & 7,8 & 27,8 & 3,7 & 50,0 & 8,5 & 33,3 & 7,5 & BPM & $\mathrm{BI}$ \\
\hline $\mathrm{E}$ & 35,7 & 4,9 & 64,3 & 4,4 & 42,9 & 4,4 & 14,3 & 1,9 & 35,7 & 6,3 & BPM & ERP \\
\hline $\mathrm{F}$ & 33,3 & 11,8 & 66,7 & 11,8 & 52,8 & 14,0 & 33,3 & 11,3 & 33,3 & 15,0 & BPM & ERP \\
\hline G & 14,9 & 6,9 & 48,9 & 11,3 & 36,2 & 12,5 & 19,1 & 8,5 & 25,5 & 15,0 & BPM & ERP \\
\hline $\mathrm{H}$ & 44,4 & 15,7 & 63,9 & 11,3 & 63,9 & 16,9 & 47,2 & 16,0 & 33,3 & 15,0 & $\begin{array}{l}\text { BPM/ } \\
\text { CRM }\end{array}$ & CRM \\
\hline I & 33,3 & 5,9 & 83,3 & 7,4 & 38,9 & 5,1 & 22,2 & 3,8 & 11,1 & 2,5 & BPM & BPM \\
\hline $\mathrm{J}$ & 40,0 & 11,8 & 53,3 & 7,8 & 53,3 & 11,8 & 53,3 & 15,1 & 26,7 & 10,0 & $\begin{array}{l}\text { BPM/ } \\
\text { CRM }\end{array}$ & BI \\
\hline $\mathrm{K}$ & 48,1 & 12,7 & 59,3 & 7,8 & 29,6 & 5,9 & 29,6 & 7,5 & 11,1 & 3,8 & BPM & DMS \\
\hline $\mathrm{L}$ & 25,0 & 3,9 & 75,0 & 5,9 & 18,8 & 2,2 & 25,0 & 3,8 & 18,8 & 3,8 & BPM & BPM \\
\hline N_IT & $\mathrm{K}$ & $\mathrm{H}$ & $\mathrm{D}$ & C & $\mathrm{H}$ & C & $\mathrm{J}$ & C & E & $\mathbf{F , G , H}$ & & \\
\hline
\end{tabular}

Legenda: * sekcji B nie uwzględniono ze względu na brak obserwacji; ** \% z danej branży; *** \% z poziomu wykorzystania danego systemu IT w próbie badawczej; N_W - największy wynik w danej sekcji; N_IT - największy wynik dotyczący danej klasy systemu IT Źródto: opracowanie wtasne

Tabela 6. Wyniki zastosowania testu U (Manna-Whitneya) (zestawienie istotnych statystycznie różnic)

\begin{tabular}{|c|c|c|c|c|}
\hline $\begin{array}{l}\text { Zmienna } \\
\text { zależna }\end{array}$ & Zbiorowość przedsiębiorstw & N & Średnia ranga & $\begin{array}{c}\text { Istotność } \\
\text { asymptotyczna } \\
\text { (dwustronna) }\end{array}$ \\
\hline \multirow{2}{*}{ DMS (1) } & Dominująca aktywność gospodarcza w sekcji G & 47 & 125,29 & \multirow{2}{*}{$0,004^{*}$} \\
\hline & Dominująca aktywność gospodarcza w innych sekcjach & 259 & 158,62 & \\
\hline \multirow{2}{*}{ BPM (1) } & Dominująca aktywność gospodarcza w sekcji D & 18 & 187,50 & \multirow{2}{*}{$0,040^{*}$} \\
\hline & Dominująca aktywność gospodarcza w innych sekcjach & 288 & 151,38 & \\
\hline \multirow{2}{*}{ BPM (2) } & Dominująca aktywność gospodarcza w sekcji G & 47 & 126,37 & \multirow{2}{*}{$0,005^{\star}$} \\
\hline & Dominująca aktywność gospodarcza w innych sekcjach & 259 & 158,42 & \\
\hline \multirow{2}{*}{ CRM (1) } & Dominująca aktywność gospodarcza w sekcji H & 36 & 183,25 & \multirow{2}{*}{$0,013^{*}$} \\
\hline & Dominująca aktywność gospodarcza w innych sekcjach & 270 & 149,53 & \\
\hline \multirow{2}{*}{ CRM (2) } & Dominująca aktywność gospodarcza w sekcji L & 16 & 114,19 & \multirow{2}{*}{$0,034^{*}$} \\
\hline & Dominująca aktywność gospodarcza w innych sekcjach & 290 & 155,67 & \\
\hline \multirow{2}{*}{ BI (1) } & Dominująca aktywność gospodarcza w sekcji G & 47 & 129,80 & \multirow{2}{*}{$0,015^{*}$} \\
\hline & Dominująca aktywność gospodarcza w innych sekcjach & 259 & 157,80 & \\
\hline \multirow{2}{*}{$\mathrm{BI}(2)$} & Dominująca aktywność gospodarcza w sekcji J & 30 & 182,10 & \multirow{2}{*}{$0,024^{*}$} \\
\hline & Dominująca aktywność gospodarcza w innych sekcjach & 276 & 150,39 & \\
\hline \multicolumn{4}{|c|}{ Częstość różnicowania (dla wszystkich zastosowanych zmiennych) } & 7 \\
\hline
\end{tabular}

* $\mathrm{p} \leq 0,05$ - podawany w wynikach testu U poziom $\mathrm{p}$ reprezentuje prawdopodobieństwo błędu związanego z przyjęciem hipotezy o istnieniu różnic między grupami

Źródto: opracowanie wtasne 
do usprawnienia i zracjonalizowania procesu podejmowania decyzji strategicznych w przedsiębiorstwie.

Kolejny rodzaj systemów IT, czyli systemy klasy DMS, pozwalają na usprawnienia $\mathrm{w}$ zakresie organizacji pracy i obiegu dokumentów w przedsiębiorstwie. Poziom wskazań respondentów nie pozwala jednak na optymizm w ocenie wykorzystania systemów DMS, właściwych z punktu widzenia wspomagania systemów informacyjnych w wyborach strategicznych, bo z definicji nie są one wyposażone w oprogramowanie pozwalające na formułowanie i wyjaśnianie scenariuszy rozwoju otoczenia oraz skutków dla przedsiębiorstw. W próbie badawczej korzysta $\mathrm{z}$ nich ok. 1/3 przedsiębiorstw (33,33\% - 102 podmioty).

Bardziej optymistyczne są wyniki opisujące stosowanie w procesach wyborów strategicznych systemów klasy CRM (44,44\% - 136 podmiotów). Badane przedsiębiorstwa wpisują się w profil przedsiębiorstw w Polsce wykorzystujących systemy informatyczne CRM, ustalony przez badania GUS. Według informacji GUS, w 2015 roku 42,2\% średniej wielkości przedsiębiorstw, a rok wcześniej 37,7\% przedsiębiorstw korzystało z systemów klasy CRM (GUS, 2015, s. 103). Należy jednak uwzględnić fakt, że systemy te nie są traktowane jako fundamentalne do podejmowania decyzji strategicznych. Wspomagają jednak między innymi opis i wyjaśnienie relacji z odbiorcami i ich skutków.

W dalszym postępowaniu badawczym eksploracja danych pozwoliła zaprezentować rozkład wyników dotyczący poziomu wykorzystania systemów IT komentowanych ze względu na dominujący sektor działalności gospodarczej (tab. 5). Najwyższe wskaźniki korzystania z systemów IT w procesach wyborów strategicznych stanowią, jak wspomniano wyżej, systemy klasy BPM i dotyczą wszystkich rozważanych sektorów gospodarki, podobnie jak systemy klasy CRM (tu względnie wyższe wskazania dotyczą przedsiębiorstw kwalifikowanych w sekcji $\mathrm{H}$ - transport i gospodarka magazynowa i J - informacja i komunikacja).

Relatywnie wysokie wskaźniki wykorzystania systemów IT w procesach wyborów strategicznych uzyskano dla:

- systemów klasy DMS $(15,7 \%)$ w transporcie i gospodarce magazynowej $(\mathrm{H})$,

- systemów klasy BPM (16,2\%), systemów klasy CRM $(17,6 \%)$, systemów klasy BI $(17,0 \%)$ w przetwórstwie przemysłowym (C),

- systemów klasy ERP (15,0\%), wśród których te same poziomy wskazań otrzymano dla przedsiębiorstw działających $\mathrm{w}$ budownictwie $(\mathrm{F})$, handlu i naprawie pojazdów samochodowych $(G)$ oraz transporcie i gospodarce magazynowej (H).

Nie bez znaczenia pozostaje fakt, że dla czterech $\mathrm{z}$ jedenastu wybranych sekcji PKD (A, E, F, G), najwyższe wskaźniki wykorzystania systemów IT przez kadrę kierowniczą wyższego szczebla uzyskano dla systemów klasy ERP. Obejmują one rozwiązania informatyczne pozwalające na wspomaganie zarządzania wszystkimi komórkami organizacyjnymi przedsiębiorstwa. Jednocześnie stanowią niezbędne wsparcie w identyfikowaniu i prognozowaniu zmian w otoczeniu. Są również traktowane jako podstawa do wdrażania nowych technologii, a zarazem rozwoju i inwestycji w ramach koncepcji Przemysłu $4.0 \mathrm{w}$ przedsiębiorstwach.

\section{Wykorzystywanie systemów IT we wspomaganiu wyborów strategicznych w przedsiębiorstwach działających w różnych sektorach}

$\mathrm{Z}$ dotychczasowych prac badawczych i analiz przedstawionych $\mathrm{w}$ artykule wynika, że przedsiębiorstwa różnią się $\mathrm{w}$ zakresie informacyjnego wspomagania wyborów strategicznych przez systemy IT. Dokładna analiza umożliwiła wskazanie istotnych statystycznie różnic pomiędzy przedsiębiorstwami o odmiennej aktywności gospodarczej. Zastosowanie testu U wymagało podziału badanej zbiorowości przedsiębiorstw na dwa zbiory. Do pierwszego (1) zakwalifikowano podmioty deklarujące dominujący sektor działalności gospodarczej, natomiast do drugiego (2) jednostki, te w których przeważa inna prowadzona podstawowa aktywność. Otrzymane wyniki zaprezentowano w tabeli 6 .

Na podstawie analizy danych empirycznych stwierdzono, że przedsiębiorstwa charakteryzujące się dominującą działalnością w zakresie:

- handlu i naprawy pojazdów samochodowych (sekcja G) różnią się poziomem korzystania z systemów klasy DMS (1), BPM (2) oraz BI (1) od pozostałych przedsiębiorstw;

- wytwarzania i zaopatrywania w energię elektryczną, gaz, parę wodną i gorącą wodę (sekcja D) różnią się poziomem korzystania z systemów klasy BPM (1) od innych przedsiębiorstw;

- transportu i gospodarki magazynowej (sekcja H) różnią się poziomem korzystania z systemów klasy CRM (1) od pozostałych przedsiębiorstw;

- obsługi rynku nieruchomości (sekcja L) różnią się również poziomem korzystania z systemów klasy CRM (2) od pozostałych przedsiębiorstw;

- zakwaterowania i gastronomii (sekcja J) różnią się poziomem korzystania z systemów klasy BI (2) od innych przedsiębiorstw.

\section{Podsumowanie}

yniki badania stanowią źródło informacji dla innych badaczy oraz wskazówki dla praktyków, w tym przede wszystkim osób należących do wyższego szczebla kierownictwa, komitetów sterujących, ale także doradców, menedżerów, analityków i specjalistów ICT oraz twórców systemów IT, producentów i dostawców oprogramowania.

Względna odrębność wybranych systemów IT pozwoliła poznać poziom ich wykorzystania $\mathrm{w}$ procesach wyborów strategicznych przedsiębiorstw działających w różnych sektorach. Rozważania i sugestie literaturowe nie znalazły w pełni potwierdzenia w badaniu. Relatywnie wysokie wskaźniki wykorzystania systemów klasy BPM i DMS świadczą o powszechnym korzystaniu w procesie wyborów. Wobec ich ograniczonych możliwości identyfikowania i wyjaśniania struktury przyszłego otoczenia oraz sposobów zachowania przedsiębiorstw w perspektywie strategicznej udział we wspomaganiu wyborów strategicznych jest mniej istotny (w porównaniu do możliwości systemów klasy ERP, BI i CRM).

Zastosowanie testu U pozwoliło na częściowo pozytywną weryfikację hipotezy badawczej - „przedsiębiorstwa 
funkcjonujące w różnych sektorach działalności gospodarczej charakteryzują się odmiennym poziomem wykorzystania systemów IT w wyborach strategicznych". Do takiego wniosku skłoniły wyniki, w szczególności w przypadku przedsiębiorstw funkcjonujących w sektorach - handlu i naprawy pojazdów samochodowych, wytwarzania i zaopatrywania w energię elektryczną, gaz, parę wodną i gorącą wodę, transportu i gospodarki magazynowej, obsługi rynku nieruchomości oraz zakwaterowania i gastronomii.

Wnioski z badań pozwalają na przedstawienie następujących rekomendacji:

- prowadzenie analiz dotyczących informacyjnego wspomagania wyborów strategicznych ze względu na inne cechy charakteryzujące przedsiębiorstwa ( $w$ rozumieniu mikro, małe przedsiębiorstwa, jak również przy uwzględnieniu rodzaju kapitału i struktury właścicieli oraz sposobu zarządzania) i sektory (charakterystyka wewnątrzsektorowych zachowań konkurentów, zróżnicowania produktów, skali działania i stopnia koncentracji);

- rozszerzenie badań o szczegółowe elementy koncepcji Przemysłu 4.0 - takie jak Internet Rzeczy, Big Data, przetwarzanie $\mathrm{w}$ chmurze, $\mathrm{w}$ szczególności $\mathrm{w}$ przedsiębiorstwach, które wykazują korzystanie z systemów klasy ERP w procesach wyborów strategicznych;

- zaprojektowanie wskaźnika intensywności cyfrowej dla informacyjnego wspomagania wyborów strategicznych przez systemy IT (oprogramowanie).

Jednocześnie wskazuje się na konieczność przeprowadzenia dalszych analiz statystycznych - zwłaszcza analizy danych na podstawie szeregów czasowych, czyli sekwencji pomiarów, wydłużających horyzont wnioskowania. Zwrócić uwagę powinno się również na ograniczenia badawcze, które wynikają przede wszystkim z subiektywności ocen dokonywanych przez respondentów w badaniu ilościowym, nie bez znaczenia dla komentowania cech wspomagania informacyjnego, przedsiębiorstwa oraz sektora.

\section{prof. dr hab. Elżbieta Urbanowska-Sojkin Uniwersytet Ekonomiczny w Poznaniu Wydziat Zarządzania ORCID: 0000-0002-5019-1701 e-mail: e.sojkin@ue.poznan.pl}

\section{dr Adam Weinert \\ Uniwersytet Ekonomiczny w Poznaniu \\ Wydział Zarządzania \\ ORCID: 0000-0002-8697-8944 \\ e-mail: adam.weinert@ue.poznan.pl}

\section{Przypisy}

1) Skróty te oznaczają kolejno: ERP - Enterprise Resource Planning (systemy planowania zasobów przedsiębiorstwa), BI - Business Intelligence (systemy informacji zarządczej), CRM - Customer Relationship Management (systemy zarządzania relacjami z klientem), DMS - Document Management Systems (systemy elektronicznego zarządzania dokumenta- mi), BPM - Business Process Management (systemy zarządzania procesami biznesowymi).

2) Oprócz przedmiotowej literatury, warto odnosić się do opracowań podejmujących pośrednio podjętą problematykę. Są nimi liczne raporty branżowe ICT, publikacje służb statystycznych (GUS i Eurostat), producentów IT (m.in. Microsoft, IBM) i firm analityczno-badawczych (np. Gartner).

\section{Bibliografia}

[1] Banaszak Z., Kłos S., Mleczko J. (2016), Zintegrowane systemy zarządzania, Wydanie II, Polskie Wydawnictwo Ekonomiczne, Warszawa.

[2] Bedyńska S., Cypryańska M. (2013), Statystyczny drogowskaz: Praktyczne wprowadzenie do wnioskowania statystycznego, Wydawnictwo Akademickie Sedno, Warszawa.

[3] Burgelman R.A., Floyd S.W., Laamanen T., Mantere S., Vaara E., Whittington R. (2018), Strategy Processes and Practices: Dialogues and Intersections, „Strategic Management Journal”, Vol. 39, No. 3, pp. 531-558.

[4] Ghobakhloo M. (2018), The Future of Manufacturing Industry: A Strategic Roadmap toward Industry 4.0, „Journal of Manufacturing Technology Management", Vol. 29, No. 6, pp. 910-936, DOI: 10.1108/JMTM-02-2018-0057.

[5] GUS (2015), Społeczeństwo informacyjne w Polsce. Wyniki badań statystycznych z lat 2010-2015. Warszawa: Główny Urząd Statystyczny, http://stat.gov.pl/obszary-tematyczne/nauka-i-technika-spoleczenstwo-informacyjne/spoleczenstwo-informacyjne/spoleczenstwo-informacyjne-w-polsce-wyniki-badan-statystycznych-z-lat-2011-2015,1,9.html, data dostępu: 23.01.2019 r.

[6] GUS (2017), Zmiany strukturalne grup podmiotów gospodarki narodowej w rejestrze regon, I pótrocze 2017 roku. Warszawa: Główny Urząd Statystyczny, http://stat.gov.pl/obszary-tematyczne/podmioty-go-spodarcze-wyniki-finansowe/ zmiany-strukturalne-grup-podmiotow/zmiany-strukturalne-grup-podmiotow-go-spodarki-narodowej-w-rejestrze-regon-i-polrocze-2017-r-,1,20.html, data dostępu: 23.01.2019 r.

[7] GUS (2018), Spoleczeństwo informacyjne w Polsce, Wyniki badań statystycznych z lat 2014-2018, Warszawa: Główny Urząd Statystyczny, Szczecin: Urząd Statystyczny w Szczecinie, http:// stat.gov.pl/obszary-tematyczne/nauka-i-technika-spoleczenstwo-informacyjne/, data dostępu: 23.01.2019 r.

[8] Herbert L. (2017), Digital Transformation: Build Your Organization's Future for the Innovation Age, Bloomsbury.

[9] http://www.comarch.pl/, access date: 23.03.2019.

[10] Jarzabkowski P., Kaplan S. (2015), Strategy Tools-in-use: A Framework for Understanding "Technologies of rationality" in practice, „Strategic Management Journal”, Vol. 36, No. 4, pp. 537-558 , DOI: $10.1002 / \mathrm{smj} .2270$.

[11] Jurek J. (2016), Wdrożenia informatycznych systemów zarzadzania, Wydawnictwo Naukowe PWN, Warszawa.

[12] Kenworthy T.P., Verbeke A. (2015), The Future of Strategic Management Research: Assessing the Quality of Theory Borrowing, „European Management Journal”, Vol. 33, No. 3, pp. 179-190, DOI: 10.1016/j.emj.2015.03.007.

[13] Kisielnicki J. (2009), Typologia systemów informatycznych zarządzania, Zeszyty Naukowe Uniwersytetu Szczecińskiego, Studia Informatica, Vol. 24, Nr 576, s. 157-167. 
[14] Larsen K.R., Allen G., Vance A. i Eargle D. (2014), Theories Used in IS Research Wiki, http://istheory.byu.edu, access date: 04.01.2019.

[15] Laudon K.C., Laudon J.P. (2014), Management Information Systems. Managing the Digital Firm, 13th Edition, Pearson/ Prentice Hall, New York.

[16] Matyjas Z. (2013), Wzorce konkurowania przedsiębiorstw $w$ sektorach - podejście dynamiczne, Wydawnictwo Uniwersytetu Łódzkiego, Łódź.

[17] Microsoft Dynamics NAV (2018), Nowości w systemie ERP. Microsoft Dynamics NAV 2018. Wspiera cyfrowa transformacje biznesu, https://www.dynamicsnav.pl/wp-content/ uploads/2018/03/Co-nowego-Mi-crosoft-Dynamics-NAV-2018.pdf, data dostępu: 23.01.2019 r.

[18] NBP (2018), Szybki monitoring NBP, Analiza sytuacji sektora przedsiębiorstw, https://www.nbp.pl/publikacje/koniunktura/ raport_4_kw_2018.pdf, data dostępu: 23.01.2019 r.

[19] Olszak C. (red.), (2017), Twórcza organizacja, Komputerowe wspomaganie twórczości organizacyjnej, Wydawnictwo C.H. Beck, Warszawa.

[20] Pearlson K.E., Saunders C.S., Galletta D.F. (2016), Managing and Using Information Systems: A Strategic Approach, 6th Edition, John Wiley \& Sons, New York.

[21] Peppard J., Ward J. (2016), The Strategic Management of Information Systems - Building a Digital Strategy, 4th Edition, John Wiley \& Sons, London.

[22] Urbanowska-Sojkin E. (2010), Informacyjne wspomaganie wyborów strategicznych przedsiębiorstw $w$ warunkach niepewności - antycypacja kryzysów, „Studia i Prace Kolegium Zarządzania i Finansów", Nr 98, s. 206-214.

[23] Urbanowska-Sojkin E. (red.), (2013), Ryzyko w wyborach strategicznych w przedsiębiorstwach, Polskie Wydawnictwo Ekonomiczne, Warszawa.

[24] Urbanowska-Sojkin E. (2014), Skutki wyzwań otoczenia dla zarządzania strategicznego przedsiębiorstwem, „Studia Oeconomica Posnaniensia”, Nr 11, s. 169-194.

[25] Urbanowska-Sojkin E. (2017), Informacyjny imperatyw rozwoju przedsiębiorstwa, „Marketing i Rynek”, Nr 4, s. 401-410, CD.

[26] Wachnik B. (2016), Wdrażanie systemów informatycznych wspomagających zarzadzanie, Polskie Wydawnictwo Ekonomiczne, Warszawa.
[27] Weinert A. (2017a), Wykorzystanie systemów BIG DATA w procesie wyborów strategicznych. „Ekonomika i Organizacja Przedsiębiorstwa”, Nr 2, s. 48-57.

[28] Weinert, A. (2017b), Kierunki badawcze w kontekście zastosowania narzędzi w zarzadzaniu (strategicznym) przedsiębiorstwem, „Handel Wewnętrzny”, Nr 3(368), Tom II, s. 146-156.

[29] Weinert A., (2018), Zaawansowanie przedsiębiorstw w zakresie informacyjnego wspomagania wyborów strategicznych, Uniwersytet Ekonomiczny w Poznaniu, Poznan.

[30] Wheelen T.L., Hunger J.D. (2012), Strategic Management and Business Policy - Toward Global Sustainability (13th Edition). Pearson/Prentice Hall, New York.

\section{Application of IT Systems in Information Support of Strategic Choices in Enterprises Operating in Different Sectors}

\section{Summary}

In the face of digital transformation changing the existing ways of operation, the possibilities of shaping the future of the enterprise are conditioned by the IT systems implemented in them. The information support of strategic choices by IT systems depends on their use in the process of pursuing strategic objectives and strategies. The factors determining the level of advancement in this area are indicated by the sector of economic activity. The aim of the study is to determine the extent to which enterprises apply IT systems supporting information-oriented strategic choices on a sectoral basis. Statistically significant differences between the examined sets of enterprises have been indicated in it. The identification has been made with the use of the Mann-Whitney $U$ test. This allowed for a partially positive verification of the hypothesis that companies operating in different sectors of economic activity are characterized by a different level of IT systems application in strategic choices.

\section{Keywords}

information support of strategic choices, IT systems, determinants of strategic choices, sector of economic activity 